\title{
Efektifitas Pengembangan Model Permainan Bola Keranjang Aspek Motorik Kasar Anak 5-6 Tahun
}

\author{
Isfauzi Hadi Nugroho', Abdian Asgi Sukmana², Anik Lestariningrum ${ }^{1 凶}$, Naufal Ismail \\ Septiano' ${ }^{2}$, Agung Barokatir Rizqi ${ }^{2}$ \\ Pendidikan Guru Pendidikan Anak Usia Dini, Universitas Nusantara PGRI Kediri, \\ Indonesia(1), Pendidikan Jasmani Kesehatan dan Rekreasi, Universitas Nusantara PGRI \\ kediri, Indonesia(2)
}

DOI: 10.31004/obsesi.v6i3.1974

\begin{abstract}
Permasalahan motorik kasar anak usia 5-6 tahun dari pembelajaran daring menyebabkan anak lebih banyak beraktifitas dengan duduk di depan laptop atau gawai HP sehingga gerak motorik kasarnya kurang seperti berlari, melempar, menendang bola, senam dimana aktivitas tersebut melatih kemampuan motorik dan sensori sebagai dasar pedoman pengembangan kemampuan melalui bermain bebas yang membutuhkan gerakan syaraf otot-otot besar sangat kurang. Tujuan penelitian ini mengembangkan model permainan inovasi pembelajaran motorik kasar. Desain menggunakan pendekatan R \& D (Reseach and Development) yang menghasilkan produk mengadopsi model Borg \& Gall disederhanakan peneliti. Subjek penelitian anak kelompok B TK Perwanida Mrican Kediri. Teknik pengumpuln data lembar observasi ceklist dan wawancara. Analisis data deskriptif kuantitatif. Tahapan analisis kebutuhan permainan, instrument dan model permainan di validasi dan uji coba kelompok kecil. Hasil menunjukan efektifitas pengembangan model permainan aspek motorik kasar anak usia 5-6 tahun valid, praktis dan memiliki potensi dapat digunakan seluruh guru ketika proses pembelajaran motorik kasar.
\end{abstract}

Kata Kunci: efektifitas; model permainan; bola keranjang; motorik kasar; anak 5-6 tahun

\begin{abstract}
Gross motor problems of children aged 5-6 years from online learning cause children to be more active by sitting in front of a laptop or cellphone so that their gross motor movements are less such as running, throwing, kicking a ball, gymnastics where these activities train motor and sensory skills as a basic guideline. ability development through free play which requires nerve movement of large muscles is very less. The purpose of this research is to develop a gross motor learning innovation game model. The design uses an R \& D (Reseach and Development) approach which results in the product adopting the simplified Borg \& Gall model of the researcher. The research subjects were group B children of Perwanida Mrican Kediri Kindergarten. Techniques for collecting data, observation sheets, checklists and interviews. Quantitative descriptive data analysis. The stages of analyzing the needs of games, instruments and game models are validation and small group trials. The results show that the effectiveness of the development of the gross motor aspect game model for children aged 5-6 years is valid, practical and has the potential to be used by all teachers during the gross motor learning process.
\end{abstract}

Keywords : effectiveness, game model, basketball, gross motor skills, children 5-6 years old

Copyright (c) 2021 Isfauzi Hadi Nugroho, et al.

$\triangle$ Corresponding author:

Email Address : isfauzi@unpkediri.ac.id, (Kediri, Indonesia)

Received 19 August 2021, Accepted 13 December 2021, Published 29 December 2021 


\section{PENDAHULUAN}

Stimulasi tumbuh kembang seorang anak harus dilakukan secara menyeluruh pada seluruh aspek perkembanganya, karena satu dengan lain akan mempengaruhi pada pencapaian tahap selanjutnya. Pondasi dari awal diberikan secara kuat akan diperoleh hasi optimal pada tahapan selanjutnya apalagi dengan karakteristik anak usia dini yang unik dan usia 5-6 tahun masuk pada tahapan pra-operasional dimana sangat dibutuhkan model permainan kreatif yang dapat digunakan guru khususnya mendukung pembelajaran saat pandemi. Apalagi pembelajaran daring di masa pandemi sekarang mempengaruhi perkembangan karena sebagian aspek mengalami penurunan yang tertinggi adalah aspek sosial emosional dan fisik. Motorik kasar merupakan keterampilan dapat dianggap sebagai gerakan yang terlibat dalam koordinasi lengan, kaki, dan bagian serta gerakan tubuh besar lainnya. Keterampilan motorik kasar adalah gerakan seperti berlari, merangkak, berenang atau melompat. Jenis gerakan ini penting untuk dilatih oleh anak kecil saat mereka berkembang karena membantu anak belajar bagaimana mengoordinasikan dan mengontrol gerakan tubuh mereka. Keterampilan motorik kasar juga membantu meletakkan dasar untuk dapat menyelesaikan gerakan keterampilan motorik halus. Penelitian yang dilakukan oleh (Putri, 2019) merancang kegiatan bermain melalui penelitian tindakan kelas melalui kegiatan melempar dan menangkap bola dimana ditegaskan pada penempatan badan, kaki, posisi berdiri dnegan pelurusan siku, ada koordinasi mata dimana menegaskan penggunaan otototot besar syaraf anak. Dengan kata lain pentingnya pengembangan motorik kasar dilakukan pada anak berkaitan dengan stimulasi otot besar serta sebagai upaya agar anak melakukan gerakan bebas karena pembelajaran saat daring membuat kurang bergerak baik pada anak laki-laki maupun anak perempuan.

Ditegaskan oleh Papalia, D.E., Olds, S.W., Feldman dalam (Arifiyanti, 2020) Preschool children make great advanced in gross motor skills, such as jumping, running, walking, climbing, which involve the large muscle setelah diterapkan ditemukan hasil bahwa ada perbedaan pencapaian keterampilan motorik kasar dari anak perempuan dan laki-laki dimana pencapaian anak lakilaki lebih tinggi. Hal ini menumpuhkan konsep dalam rancangan pembelajaran tidak seharusnya melihat pada gender karena keterampilan motorik kasar merupakan bagian penting dari perkembangan anak usia dini. Memantau perkembangan keterampilan motorik kasar ini untuk menentukan apakah anak Anda berada di jalur yang tepat adalah penting, tetapi pada saat yang sama ingat bahwa semua anak berkembang dengan kecepatan yang berbeda. Pengembangan area motorik di otak membuat mereka dapat mengkoordinasikan indera dan apa yang ingin mereka lakukan. Tambahkan dengan rasa ingin tahu mereka yang mendalam dengan dunia ini dan dengan penuh energi, anak bisa selalu bergerak dari satu sisi ke sisi lain. Selain itu hasil paparan (Honrubia-Montesinos et al., 2021) analisis nonparametrik menunjukkan bahwa ada perbedaan antara anak perempuan dan laki-laki dalam keterampilan lokomotor dan kontrol objek pada rentang usia 3-4 tahun. Namun, anak laki-laki dan perempuan memiliki skor yang sama pada usia 5 tahun dalam perkembangan lokomotor. Hal ini nantinya bisa dijadikan oleh pendidik apabila melakukan perancangan dan penilaian sesuai tema yang sudah ada di sekolah masing-masing mengacu pada persamaan capaian anak. Tidak perlu membuat stimulasi permainan gerakan kasar anak memilih untuk anak laki maupun perempuan sehingga permainan yang dirancang untuk anak usia dini dapat dilakukan semua jenis kelamin hanya nantinya mungkin pengelompokan saat bermain saja jika dilombakan beregu melihat kelompok jenis kelamin.

Pentingnya pengembangan aspek motorik kasar menjadi bahan kajian diperhatikan oleh guru dan orang tua. Anak yang memiliki kemampuan motorik kasar yang baik akan lebih luwes dalam bergaul dengan teman-temannya. Hal ini tentu saja akan berpengaruh pada kepercayaan diri anak saat bersosialisasi dengan teman-temannya. Pernyataan Alzena Masykouri, dalam (Mahmud, 2019) bahwa anak yang memiliki kemampuan motorik kasar yang baik akan membuatnya menjadi lebih gesit dan sigap. Gerakannya menjadi lebih terkoordinasi dan membuat anak tampil lebih percaya diri. Hal ini akan membuat anak 
mampu bersikap luwes dalam pergaulannya. Ketercapaian koordinasi gerakan optimal berdampak sikap perencanaan sehingga semakin terampil dalam menyelesaikan persoalan sehari-hari yang dihadapinya. Hal ini jika dikaitkan dengan kondisi setelah anak-anak belajar saat di rumah selama pandemi Covid-19 dimana guru harus merencanakan pembelajaran yang menarik disesuaikan dengan cara belajar anak kurang gerak, pasif karena sering duduk perlu dilakukan perencanaan pembelajaran motoric. Dikuatkan oleh (Safitri \& Izzati, 2021) ketika melakukan penelitian dengan merancang tema yang sesuai dimasukan pada gerakan bermain yang memberikan kesempatan anak bergerak lebih luas sehingga anak merasa sangat senang melakukan beragam aktivitas baik dalam ruangan maupun di halaman sekolah. Intinya konsep pengembangan terkait kemampuan dasar terhadap motorik anak usia dini memiliki tujuan dalam meningkatkan beragam kemampuan terkait mengelola, mengontrol gerakan tubuh terkait koordinasi, serta keterampilan mengolah otot tubuh dimana gerakangerakan yang dilakukan secara bebas di luar ruangan akan lebih mendukung (Jannah \& Lestariningrum, 2018).

Observasi awal analisis kebutuhan dilakukan oleh peneliti pada lembaga TK di Kecamatan Mojoroto Kota Kediri ditemukan tentang fakta permasalahan pengembangan motoric kasar yang dilakukan lembaga TK selama pandemi pembelajaran daring guru menggunakan video diambil dari you tube, guru hanya menuliskan di kegiatan harian yang diberikan kepada orang tua dengan kegiatan yang dilakukan bersama orang tua dirumah dan kadang-kadang guru mengajak anak senam langsung saat di online. Akan tetapi, guru mengalami kesulitan dengan ragam kegiatan bermain khususnya untuk motorik kasar anak juga melihat gerak anak saat di pembelajaran online. Dimana guru tidak bisa melihat secara langsung tingkat pencapaian keseimbangan, kelincahan, ketepatan anak dalam melakukan gerakan melalui strategi kegiatan yang dilakukan. Sementara penelitian yang dilakukan oleh (Sumiyati, 2018) dimana keseimbangan, kesiapan persendian dan kekuatan otot sebagai sasaran awal perkembangan motorik anak harus dikembangkan dengan permainan edukatif terutama melatih ketangkasan supaya anak mampu menggunakan kekuatan atau otot-otot besarnya. perkembangan motoric kasar anak kurang diperhatikan karena kondisi yang tidak memungkinkan guru melaksanakan pembelajaran diluar, dimana membawa pengaruh karena peran orang tua menjadi sangat penting dalam pencapaian perkembangan anak dimana anak menjadi malas bergerak, hanya saat dengan gurunya saja di video call, google meet itupun dilakukan dengan dominasi banyak duduk dari pada bergerak bebas. Perubahan permainan yang akan dilakukan juga didasari permasalahan tersebut dan juga penelitian oleh (Andriani et al., 2019) mengembangkan pola gerak dasar lokomotor, non lokomotor dan manipulative melalui lari estafet dilanjutkan (S. et al., 2020) mengembangkan media melalui aplikasi gerak lokomotor menjadi ide gabungan yang akan digunakan dalam pembelajaran motori kasar. Pembelajaran daring sangat menghambat khususnya kegiatan motori kasar anak yang membutuhkan ruang bebas, meskipun orang tua sudah mengirimkan video hasil anak bergerak di rumah tetapi anak terlihat kurang dapat menikmati saat melakukan kegiatan tersebut.

Permainan bola keranjang menjadi salah satu alternatif yang dipilih terkait pengembangan motoric kasar anak usia 5-6 tahun dengan alasan karena permainan ini berbeda dan memiliki unsur unik, menarik atau menyenangkan, terdapat unsur kompetisi, unsur gerak fisik yanag bersifat aerobik serta keterampilan yang hampir semua anak-anak bisa melakukannya yaitu menendang dan menyundul (Sukmana, Abdian Asgi. Mutohir, Toho cholik. Muhyi, 2021). dimana permainan yang sebenarnya adalah kwranjang berbagai persyaratan yaitu adanya unsur olahraga, ada cerita filosofi dari olahraga tersebut, terdapat unsur tradisional dan terdapat unsur kompetisinya. Permainan yang akan dikembangkan khusus dalam penelitian ini karena sasarannya nanti untuk usia 5-6 tahun akan mengangkat bola keranjang bukan kwranjang yang gabungan sepak takraw dan permainan tradisional. Permainan ini dikombinasi dengan model bola keranjang, berdasar tulisan (Indriharta \& Pembangunan, 2006) dimodifikasi melalui karya (Sukmana, Abdian Asgi. Mutohir, Toho 
cholik. Muhyi, 2021) diarahkan pada permainan beregu tetapi dasar-dasar terkait pola permainan menggunakan teknik-teknik individu yang harus dikuasai oleh anak secara terus menerus proses nya diujicobakan pada anak jenjang SD. Alasan pada pengembangan penelitian di artikel ini pada anak usia 5-6 tahun dimana capaian keterampilan merupakan gambaran kemampuan motorik seseorang yang ditunjukkan melalui penguasaan suatu gerakan apabila harus mengadopsi kwranjang kalau diterapkan anak masih mengalami kesulitan karena permainan sepaktakraw memiliki teknik dasar utama dan teknik dasar lanjutan. Oleh karena itu, pengembangan akan dilakukan dengan bola keranjang anak memasukan dengan teknik melempar ke dalam sebuah wadah tetapi dnegan teknik berdiri yang benar karena suatu proses pembelajaran motorik, seorang pembelajar diharapkan mampu.-nenguasai keterampilan motorik, yaitu kemampuan seseorang untuk melakukan suatu tugas gerak secara maksimal sesuai dengan kemampuannya (Siregar, 2018). Selain itu akan dilakukan bagaimana anak bermain dalam pencapaian keterampilan dasar melompat baik tumpuan satu kaki maupun dua kaki untuk menguatkan dasar kaki keseimbangan, kelincahan dan juga unsur kesulitan gerakan sesuai usia anak.

Berdasarakan uraian yang sudah dipaparkan tujuan penelitian akan mengembangkan permainan bola keranjang sebagai model kegiatan bermain yang difokuskan pada motorik kasar anak usia dini usia 5-6 tahun. Urgensi penelitian pengembangan model permainan bola kerajang untuk strategi kegiatan permainan yang digunakan dalam pembelajaran anak yang dikembangkan khusus untuk motorik kasar terutama agar anak memiliki ketangguhan fisik dan variasi kegiatan untuk terus bergerak meskipun pembelajaran tatap muka belum dilakukan. Ragam teknik dasar yang akan dilakukan dengan melompati ban bekas, melompat di kayu, melompat bertumpu dua kaki dengan bangku, melempar bola ke dalam keranjang dimana ujung akhirnya akan mengaraahkan pada teknik permainan kwranjang sederhana untuk anak usia 5-6 dikembangkan melalui instrument indicator ketercapaian kompetensi motorik kasar di STPPA (Standar Tingkat Pencapaian perkembangan Anak). Selain itu tidak boleh dilupakan konsep bermain pada anak dimana bermain akan sebagai cara belajar dimana salah satunya pada kinestetik dibutuhkan stimulasi ragam gerak supaya energy anak tersalurkan dengan optimal (Ardini P \& Lestariningrum A, 2018). Selain itu disebutkan ketika anak melakukan permainan bola keranjang dasar aktivitas gerak yang memuat unsur-unsur olag raga dimana memunculkan pada anak-anak melibatkan dirinya dalam suatu gerak olahraga yang menjadi sebuah kebutuhan anak. Selain hal tersebut terdapat gerak berjalan, berlari menendang, menyundul, melempar dengan bola akan semakin luas cakupan gerak anak untuk kekuatan tubuhnya (Sukmana, Abdian Asgi. Mutohir, Toho cholik. Muhyi, 2021).

\section{METODOLOGI}

Metode yang digunakan dalam penelitian adalah research and development $(R \in \mathcal{E} D)$. Metode ini dipilih sesuai dengan tujuan dan sasaran yang akan ditujukan yaitu untuk menemukan dan mengembangkan model permainan bola keranjang menjadi model permainan edukatif yang akan digunakan dalam pembelajaran anak usia dini aspek motorik kasar. Pengembangan model pembelajaran berlandaskan pada teori konstruktivisme dengan pemilihan model Borg dan Gall, dari 10 langkah diadopsi oleh peneliti karena keterbatasan penelitian menjadi 7 tahap yaitu (1) studi pendahuluan menetapkan permasalahan dimana responden adalah anak usia 5-6 tahun di TK Perwanida Mrican melalui responden langsung semua anak berjumlah 30 anak terbagi dalam 4 kelas B1, B2, B3 dan B4, (2) perancangan model permainan bola keranjang dimana peneliti akan menetapkan panduan kegiatan melalui rancangan pembelajaran dan penyusunan buku panduan, (3) validasi dimana akan dilakukan pemilihan validator materi dan validator ahli olah raga gerak dasar melalui instrument yang dikembangkan peneliti, (4) ujicoba kelas kecil sejumlah 15 anak dari 4 kelas secara random pengaturan masuk tatap muka terbatas sesuai jadwal yang ditentukan lokasi penelitian, (5) revisi dilakukan dengan FGD untuk melakukan refleksi stratgi rancangan permainan, (6) ujicoba kelompok besar di 30 anak kelas B1, B2, B3 dan B4 diperoleh data valid, (7) ditemukan 
model permianan dan dilengkapi buku panduan dimana belum dilakukan diluar TK Perwanida Mrican untuk uji coba besar kelompok. Desain penelitian diilustrasikan pada gambar 1.

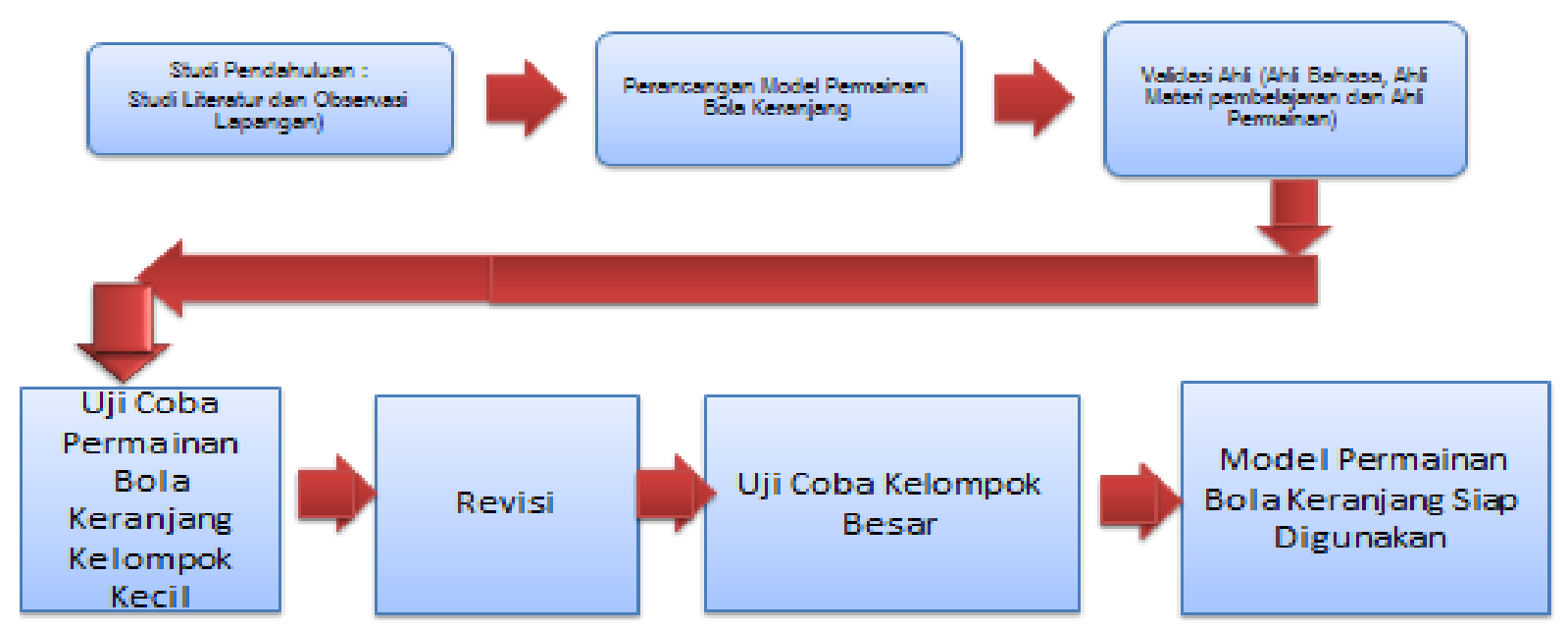

Desain Penelitian: Borg and Gall Diadopsi Peneliti 7 Tahapan

(Sumber:Peneliti 2021)

Gambar 1. Tahapan Pengembangan Model Permainan Bola Keranjang Untuk Motorik Kasar Anak Usia 5-6 Tahun Adaptasi dari Model Borg \& Gall

(Gall et al., 2005)

\section{HASIL DAN PEMBAHASAN}

\section{Analisis Kebutuhan}

Dimulainya penelitian yang dilakukan anggota tim dikuatkan dengan memetakan keterkaitan masalah terkait kurang optimalnya capaian aspek motorik kasar anak usia 5-6 tahun dan model permainan berdasarkan wawancara dengan lembaga TK Kecamatan Mojoroto. Semua anggota tim melakukan diskusi serta pemetaan dari hasil penelitian terdahulu anggota tim kemudian 1 lembaga TK menyetujui ikut dalam kegiatan penelitian dengan memebrikan alas an jumlah responden dari semua TK di Kecamatan Mojoroto Kota Kediri jumlahnya terbanyak dan jadwal saat PTM terbatas anak memenuhi untuk pengambilan data.

\section{Perancangan Model Permainan Bola Keranjang}

Membuat job deskripsi, membuat alur produk sesuai spesifikasi model yang akan dikembangkan melalui kegiatan Focus Group Discussion (FGD). Pembagian tugas saat (FGD) sebagai ketua peneliti: memimpin FGD, menulis draf alur rancangan model, anggota satu merancang inovasi bola keranjang dengan aspek motorik kasar berdasarkan konsep teknik olah raga secara tepat dan memberikan rekomendasi validator materi bidang pendidikan jasmani dan kesehatan, anggota dua merancang indikator instrument materi aspek perkembangan motorik kasar usia 5-6 tahun dengan mengkaji perencanaan, pengembangan tema yang sesuai dan memberikan rekomendasi validator materi bidang PAUD. Standar operasional kegiatan penelitian disusun dengan koordinasi dengan lembaga TK dan penelitia membuat strategi kegiatan dituangkan dalam buku panduan kegiatan bermain 


\section{Validasi Ahli}

Menyebarkan instrument pada ahli sesuai yang disepakati waktu FGD, Semua anggota tim bertanggungjawab pada 1 validator ahli. Adapun validator tersebut adalah bidang keilmuan materi PAUD guru kelompok B di TK Labschool, bidang kajian psikologi perkembangan anak, ahli bahasa untuk operasional baku instrument, ahli bidang Penjas (Gerak dasar pendidikan jasmani -gerak lokomotor, non lokomotor dan manipulatif) Adapun hasil dari validasi instrumen rancangan pembelajaran yang berisi 21 pertanyaan konsep materi pengembangan model permainan bola keranjang pada tabel 1. Sedangkan Masukan yang diberikan oleh masing-masing validator dapat dijabarkan pada tabel 2.

\section{Tabel 1: Hasil Pengolahan Data Validitas Instrumen Ahli Materi, Bahasa dan Ahli Permaian} Gerak Motorik

\begin{tabular}{|c|c|c|c|c|c|c|c|c|c|c|c|c|c|}
\hline & Nur & Dema & Hanggara & Nova & Ando & & & & & & \\
\hline Butir & Validator $\mathbf{1}$ & Validator 2 & Validator $\mathbf{3}$ & Validator 4 & Validator $\mathbf{5}$ & $\mathbf{s 1}$ & $\mathbf{s 2}$ & $\mathbf{s 3}$ & $\mathbf{s 4}$ & $\mathbf{s 5}$ & $\sum s$ & $\mathbf{V}$ & Keterangan \\
\hline $\mathbf{1}$ & 4 & 4 & 4 & 5 & 4 & 3 & 3 & 3 & 4 & 3 & 16 & 0,80 & Valid \\
\hline $\mathbf{2}$ & 4 & 5 & 5 & 5 & 5 & 3 & 4 & 4 & 4 & 4 & 19 & 0,95 & Valid \\
\hline $\mathbf{3}$ & 4 & 4 & 5 & 5 & 5 & 3 & 3 & 4 & 4 & 4 & 18 & 0,90 & Valid \\
\hline $\mathbf{4}$ & 4 & 5 & 5 & 4 & 3 & 3 & 4 & 4 & 3 & 2 & 16 & 0,80 & Valid \\
\hline $\mathbf{5}$ & 4 & 4 & 5 & 4 & 3 & 3 & 3 & 4 & 3 & 2 & 15 & 0,75 & Valid \\
\hline $\mathbf{6}$ & 4 & 5 & 5 & 4 & 3 & 3 & 4 & 4 & 3 & 2 & 16 & 0,80 & Valid \\
\hline $\mathbf{7}$ & 5 & 4 & 5 & 5 & 4 & 4 & 3 & 4 & 4 & 3 & 18 & 0,90 & Valid \\
\hline $\mathbf{8}$ & 4 & 5 & 4 & 5 & 4 & 3 & 4 & 3 & 4 & 3 & 17 & 0,85 & Valid \\
\hline $\mathbf{9}$ & 4 & 4 & 5 & 4 & 4 & 3 & 3 & 4 & 3 & 3 & 16 & 0,80 & Valid \\
\hline $\mathbf{1 0}$ & 3 & 5 & 4 & 4 & 4 & 2 & 4 & 3 & 3 & 3 & 15 & 0,75 & Valid \\
\hline $\mathbf{1 1}$ & 3 & 5 & 5 & 4 & 5 & 2 & 4 & 4 & 3 & 4 & 17 & 0,85 & Valid \\
\hline $\mathbf{1 2}$ & 5 & 5 & 5 & 5 & 5 & 4 & 4 & 4 & 4 & 4 & 20 & 1,00 & Valid \\
\hline $\mathbf{1 3}$ & 5 & 5 & 5 & 5 & 5 & 4 & 4 & 4 & 4 & 4 & 20 & 1,00 & Valid \\
\hline $\mathbf{1 4}$ & 3 & 5 & 4 & 5 & 4 & 2 & 4 & 3 & 4 & 3 & 16 & 0,80 & Valid \\
\hline $\mathbf{1 5}$ & 3 & 5 & 5 & 5 & 3 & 2 & 4 & 4 & 4 & 2 & 16 & 0,80 & Valid \\
\hline $\mathbf{1 6}$ & 3 & 4 & 5 & 5 & 2 & 2 & 3 & 4 & 4 & 1 & 14 & 0,70 & Valid \\
\hline $\mathbf{1 7}$ & 3 & 5 & 5 & 5 & 4 & 2 & 4 & 4 & 4 & 3 & 17 & 0,85 & Valid \\
\hline $\mathbf{1 8}$ & 3 & 4 & 5 & 5 & 2 & 2 & 3 & 4 & 4 & 1 & 14 & 0,70 & Valid \\
\hline $\mathbf{1 9}$ & 4 & 4 & 4 & 5 & 4 & 3 & 3 & 3 & 4 & 3 & 16 & 0,80 & Valid \\
\hline $\mathbf{2 0}$ & 5 & 5 & 4 & 5 & 4 & 4 & 4 & 3 & 4 & 3 & 18 & 0,90 & Valid \\
\hline $\mathbf{2 1}$ & 5 & 5 & 5 & 5 & 4 & 4 & 4 & 4 & 4 & 3 & 19 & 0,95 & Valid \\
\hline
\end{tabular}

Tabel 2. Masukan Komentar Validator

\begin{tabular}{|c|c|c|}
\hline $\begin{array}{c}\text { Nama } \\
\text { Validator }\end{array}$ & $\begin{array}{l}\text { Komentar dan Rekomendasi } \\
\text { Komentar }\end{array}$ & Rekomendasi \\
\hline Nur & $\begin{array}{l}\text { 1. Perlu perbaikan redaksi } \\
\text { 2. Sistematika urutan memakai penomoran } \\
\text { 3. Setiap kegiatan perlu ditandai dengan ketercapaian yang } \\
\text { diinginkan } \\
\text { 4. Berikan lembar evaluasi dan lembar anekdot penilaian }\end{array}$ & $\begin{array}{c}\text { Layak } \\
\text { digunakan }\end{array}$ \\
\hline Dema & $\begin{array}{l}\text { Secara keseluruhan instrumen sudah baik cukup dilakukan revisi pada } \\
\text { beberapa poin terkait tata tulis/pengetikan, penyesuaian tema untuk } \\
\text { bisa digunakan }\end{array}$ & $\begin{array}{c}\text { Sangat layak } \\
\text { digunakan }\end{array}$ \\
\hline Hanggara & $\begin{array}{l}\text { Perlu memperhatikan rencana evaluasi/ teknik penilaian yang } \\
\text { direncanakan, apakah memungkinkan bila dinilai menggunakan hasil } \\
\text { karya mengingat kegiatan yang diterapkan lebih kearah praktik } \\
\text { motorik }\end{array}$ & $\begin{array}{c}\text { Sangat layak } \\
\text { digunakan }\end{array}$ \\
\hline Nova & $\begin{array}{l}\text { 1. Kegiatan tersebut sangat layak digunakan untuk mengembangkan } \\
\text { Motorik Kasar anak usia 5-6 tahun. Langkah pelaksanaan juga } \\
\text { mudah dipahami oleh guru. Dalam setiap pelaksanaan sudah } \\
\text { mencangkup aspek perkembangan dengan kegiatan yang } \\
\text { menyenangkan. } \\
\text { 2. Pelaksanaan permainan dapat juga dibuat kelompok terdiri menjadi } 2 \\
\text { tim, agar bisa mengembangkan sikap kerja sama dengan teman }\end{array}$ & $\begin{array}{l}\text { Sangat } \\
\text { layak } \\
\text { digunakan }\end{array}$ \\
\hline Ando & $\begin{array}{l}\text { 1. Pada materi Gerakan melompat dengan sub tema binatang } \\
\text { terbang kupu-kupu, sepertinya kurang tepat jika kupu-kupu } \\
\text { diasumsikan untuk melompat, jika diarahkan ke bentuk Gerakan } \\
\text { motorik kasar lebih tepat Gerakan kupu-kupu seperti Gerakan } \\
\text { "dogding" jika melompat bisa menggunakan contoh hewan } \\
\text { katak. }\end{array}$ & $\begin{array}{l}\text { Cukup } \\
\text { layak } \\
\text { digunakan }\end{array}$ \\
\hline
\end{tabular}


Efektifitas Pengembangan Model Permainan Bola Keranjang Aspek Motorik Kasar Anak 5-6 Tahun DOI: 10.31004/obsesi.v6i3.1974

\begin{tabular}{|c|c|c|}
\hline $\begin{array}{c}\text { Nama } \\
\text { Validator }\end{array}$ & $\begin{array}{l}\text { Komentar dan Rekomendasi } \\
\text { Komentar }\end{array}$ & Rekomendasi \\
\hline & $\begin{array}{l}\text { 2. Melempar bola dalam keranjang merupakan gerakan koordinasi } \\
\text { mata tangan bukan merupakan bentuk koordinasi otot, lebih baik } \\
\text { tidak diberi sasaran cukup melempar sejauh yang siswa mampu } \\
\text { apabila tetap mengambil kemampuan otot lengan } \\
\text { 3. Setiap peralatan yang digunakan lebih baik diberi petunjuk } \\
\text { ukuran dimensi yang jelas (ukuran dalam gambar). Sehingga } \\
\text { aman dan nyaman digunakan oleh anak } \\
\text { 4. Perkuat review di penutup tentang seberapa jauh siswa berhasil } \\
\text { dalam menguasai setiap pembelajaran agar benar-benar diketahui } \\
\text { perkembangan motorik kasar mereka }\end{array}$ & \\
\hline
\end{tabular}

\section{Uji Coba Model Permainan Bola Keranjang Kelompok Kecil}

Selanjutnya dilakukan ujicoba menggunakan instrument pembelajaran kemudian membenahi dengan memasukan butir-butir capaian kemampuan motorik kasar anak usia 5-6 tahun sesuai STPPA dengan menyiapkan penilaian sebagai berikut:

Tabel 3: Lembar Observasi Penilaian Kemampuan Motorik Kasar Anak Usia 5-6 Tahun

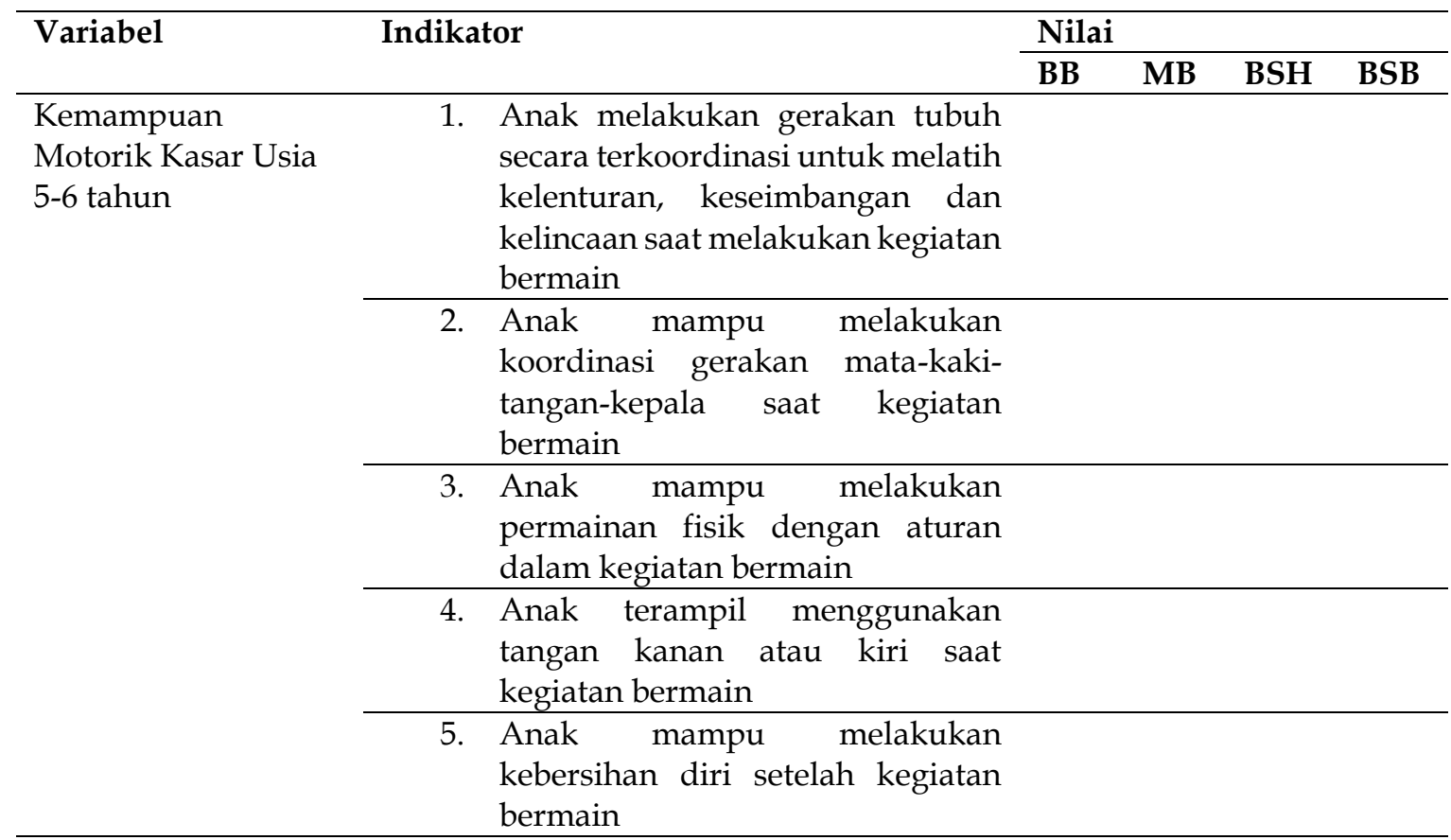

Keterangan penilaian:

BB : Jika anak melakukan dengan bimbingan dan bantuan guru

MB: Jika anak melakukan hanya diingatkan dan dibantu guru

BSH: Jika anak melakukan mandiri dan konsisten

BSB: Jika anak melakukan mandiri dan dapat membantu temannya

Berdasarkan lembar observasi tersebut diperoleh hasil pengolahan data pada tabel 4 .

Tabel 4: Uji Validitas Kriteria Item-Total Statistics

\begin{tabular}{|l|r|r|r|r|}
\hline & $\begin{array}{c}\text { Scale Mean if Item } \\
\text { Deleted }\end{array}$ & $\begin{array}{c}\text { Scale Variance if } \\
\text { Item Deleted }\end{array}$ & $\begin{array}{c}\text { Corrected Item- } \\
\text { Total Correlation }\end{array}$ & $\begin{array}{c}\text { Cronbach's Alpha } \\
\text { if Item Deleted }\end{array}$ \\
\hline Indikator_1 & 9.84 & 3.740 & .694 & .728 \\
Indikator_2 & 10.52 & 3.925 & .624 & .751 \\
Indikator_3 & 10.45 & 4.189 & .564 & .770 \\
Indikator_4 & 10.65 & 4.370 & .553 & .776 \\
Indikator_5 & 10.16 & 3.340 & .561 & .790 \\
\hline
\end{tabular}


Paparan tabel 4 dapat disimpulkan nilai indikator valid karena memiliki nilai Corrected Item-Total Correlation $\geq 0,3$ maka semua indikator dapat dinyatakan valid

Tabel 5: Uji Reliabilitas

Reliability Statistics

\begin{tabular}{|r|r|}
\hline $\begin{array}{c}\text { Cronbach's } \\
\text { Alpha }\end{array}$ & N of Items \\
\hline .801 & 5 \\
\hline
\end{tabular}

Tabel 5 menjelaskan reliabilitas yang baik jika minimal nilai Cronbach's Alpha $\geq 0,7$ sehingga reliabilitas instrument dapat dinyatakan baik.

Bukti dokumentasi pendukug saat anak-anak melakukan kegiatan bermain dapat dilihat pada gambar 2-7.

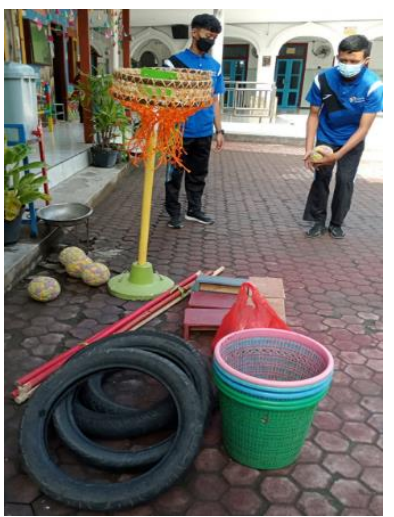

Gambar 2: Persiapan Alat/Bahan

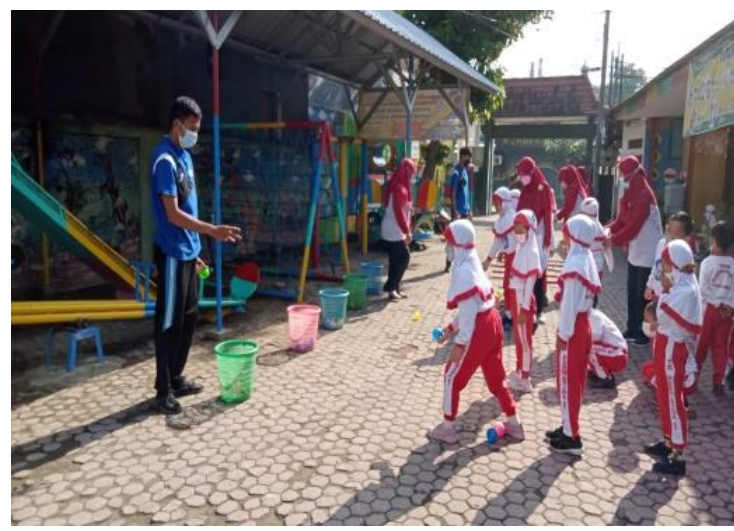

Gambar 4: Memasukan Bola Dalam Keranjang

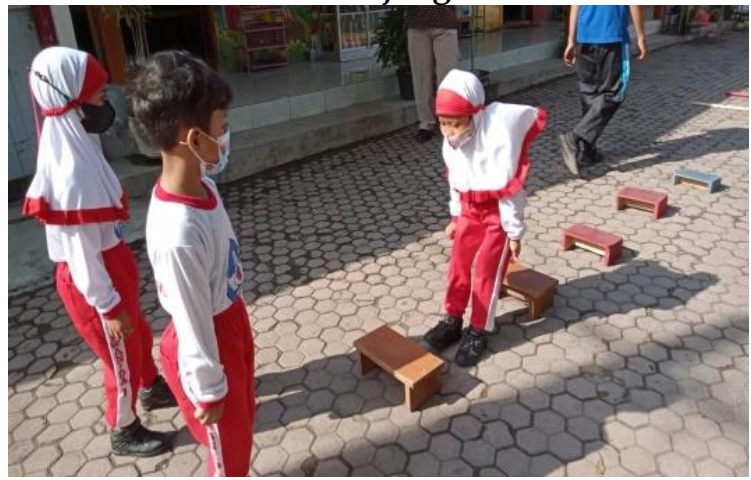

Gambar 6: Bermain Melompat Dengklek

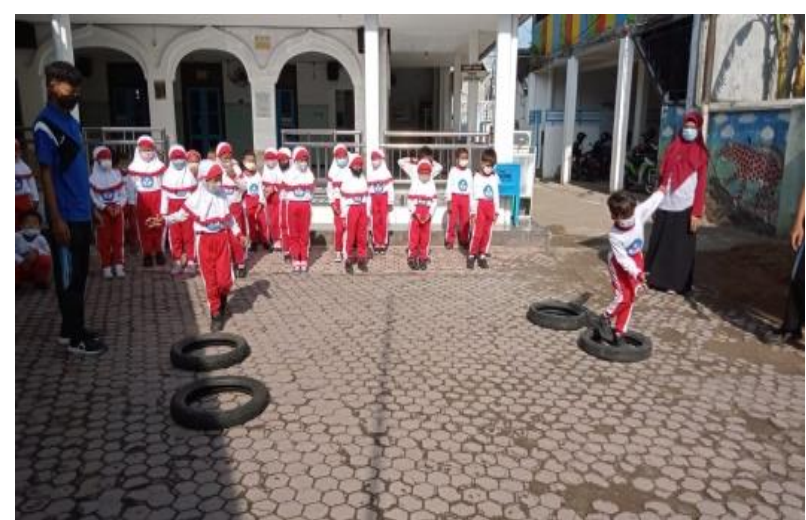

Gambar 3: Bermain Melompati Ban Bekas

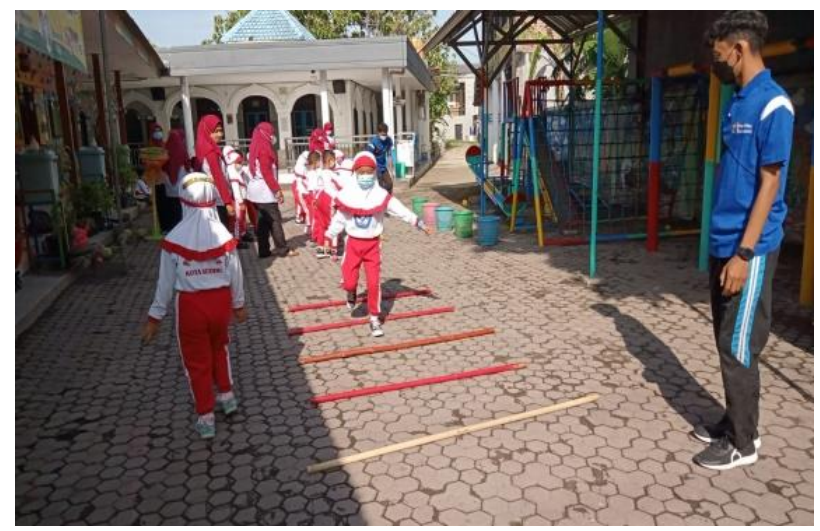

Gambar 5: Bermain Melompati Tongkat

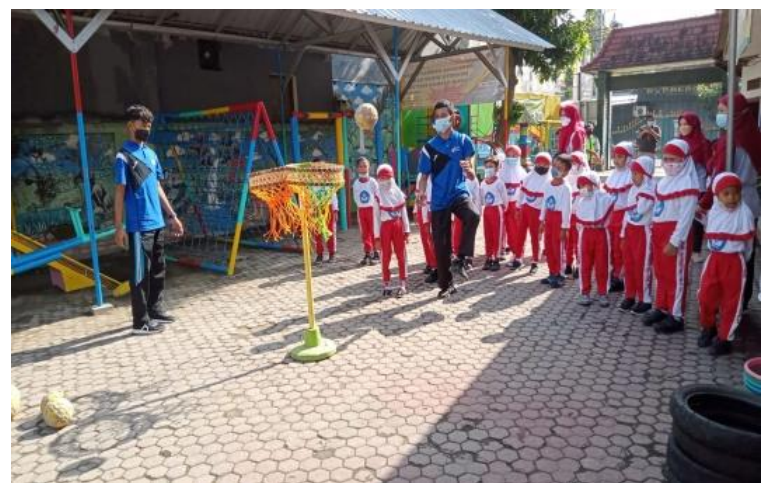

Gambar 6: Pengenalan Teknik Kwranjang 
Melalui ujicoba kelompok kecil diperoleh hasil bahwa hasil penilaian terhadap indikator pencapaian perkembangan motorik kasar memperoleh hasil cukup baik. Hal ini juga didukung melalui dokumentasi kegiatan yang menujukan bahwa gerakan bermain sudah melibatkan aktivitas lokomotor melompat, keterampilan manipulastif dngan melambungkan bola serta ada koordinasi ketangkasan , keseimbangan serta bagaimana kekuatan kaki anak juga ketelitian ketika melakukan tekanan dalam menghasilkan kombinasi gerakan tungkai serta lengan (Angraini et al., 2019). Saat anak-anak melakukan komposisi gerakan koordinasi dibutuhkan kematangan otot-otot tertentu sehingga mereka mampu berlari, meloncat, berjalan sehingga tidak jatuh juga melibatkan gerakan mata, tangan bersamaan akan dimasukan dalam perencanaan guru menggunakan tema yang sesuai (Rahma \& Kastrena, 2020). Kemampuan anak melakukan permainan fisik dengan aturan dalam kegiatan bermain juga terlihat dengan kemandirian anak dimana saat anak melakukan kegiatan yang menarik, dilakukan dengan senang, penelitian yang dilakukan oleh (Nuridayu et al., 2020) saat anakanak melakukan gerakan binatang tercipta aturan dengan menyelesaikan kegiatan bermain seluruh alat yang disediakan dan anak merasa sangat antusias juga terlihat dengan melakukan kegiatan bermain mendapatkan keceriaan meskipun dalam pembimbingan.

Saat pemanfaatan ban bekas juga terlihat spontanitas anak dimana terjadi penggabungan indra bersamaan dengan gerakan. Penelitian yang dijabarkan (Asriansyah \& Mahendra, 2020) saat anak-anak banyak yang kejanduan game online berpengaruh pada tingkat perseptual motorik dikembangkan permainan jasmani melalui permainan balap ban dimana hasil penelitian menunjukan kesadaran aturan, ada latihan berupa kesadaran komitmen, sabar menunggugiliran serta jika dikombinasi kelompok ada latihan kompetisi. Data ini didukung juga oleh (Komaini, 2017) dimana gerak dasar terasah dengan aktivitas bermain saat aktif bergerak akan berdampak hasil optimal dibandingkan anak yang kurang aktif dalam kebebasan bergerak. Ini harus didukung dalam rancangan pembelajaran guru mengaitkan strategi yang diterapkan saat kegiatan bermain tersebut. Latihan koordinasi saat kegiatan bergerak aktif dibutuhkan dimana keberanian, kekuatan otot serta kemampuan diperlukan dalam mempersiapkan jadwal latihan secara berkelanjutan. Harahap \& Seprina dalam (Syafril et al., 2020) menegaskan olah raga berkaitan dengan capaian kinerja dimana keterampilan dasar harus disiapkan sejak usia kanak-kanak oleh sebab itu stimulasi harus dilakukan dengan beragam variasi permainan motorik.

Pemaparan hasil (Nugraha, 2015) semua gerakan ketika menimbulkan gerak/motoric akan melibatkan gerakan keseluruhan tubuh dimana akan terlibat sebuh unsur penentu yaitu kematangan serta adanya pengendalian unsur utama gerak tubuh. Semakin anak akan banyak dalam gerakan semakin banyak manfaat yang diperoleh sekaligus semakin terampil dimana unsur jasmani kebugaran, kekuatan, kelincahan, daya tahan, kelenturan dan keseimbangan akan terwujud. Aktivitas olah raga juga dipersiapkan untuk pencapaian prestasi dimana ini harus dilakukan sejak anak masih mudah dalam membangun kesiapanya fisik serta mentlnya sejak dini. Beragam upaya dipersiapkan tentunya melalui pembelajaran berbasis tema di PAUD akan mendukung bagaimana bola keranjang sebagai bagian model permainan motorik dilandaskan pada pendidikan jasmani yang tetap mengedepankan etika yaitu saat selesai bermain anak segera memiliki tanggngjawab kebersihan diri, anak memiliki kebiasaan dan perilaku melalui kehidupan sehari-harinya dengan sering melakukan gerak aktif dan mendapatkan kesempatan dalam melakukan koordinasi secara menyeluruh terutama memodifikasi bola keranjang tetapi dengan memegang teknik yang benar (Indriharta \& Pembangunan, 2006) . salah satu pengkombinasian kreatifitas bola keranjang dikenalkannya teknik sepak takraw dasar melalui permainan krawnjang kemudian dari modul permainan kids takraw (Sukmana, Abdian Asgi. Mutohir, Toho cholik. Muhyi, 2021) dimana bentuk permainan nantinya sebagai tindak lanjut pengenalan kolaborasi berkelompok melalui aturan sederhana yang bisa dipahamkan anak dalam menjawab tantangan pembinaan akan disesuaikan dengan tinggi jangkauan anak serta akan dimainkan baik dalam ruangan 
maupun luar ruangan. Hal ini juga sebagai penguatan bahwa pembelajaran saat pandemi dengan lebih banyak menggunakan gadget akan secara perlahan dapat dikurangan melalui kegiatan tatap muka terbatas diterapkan model permainan yang dihasilkan. Hasil penelitian gadget sebagai tantangan orang tua kondisi milenial menurut (Novianti \& Garzia, 2020) generasi modern tetap menggunakan dukungan teknologi tetapi guru dan orang tua harus bekerjasama agar anak tetap mendapatkan layanan kesempatan bergerak bebas dan aktif.

\section{SIMPULAN}

Pengembangan model permainan bola keranjang untuk mengembangkan motorik kasar anak usia 5-6 tahun dinyatakan memiliki keefektifan. Terbukti dari hasil sampai uji coba kelompok besar diperoleh peningkatan keterampilan gerakan dasar yang melibatkan koordinasi syaraf otot besar anak dan juga kemampuan anak mengalami peningkatan terlihat dari kelincahan, kekuatan kaki saat melompat tumpuan satu atau dua kaki dan semua dilakukan anak dengan menyenangkan dan gembira mengingat cara belajar anak dnegan bermain dan memberikan kesempatan anak bergerak bebas. Disarankan untuk tindak lanjut melihat keefektifan dapat dilakukan uji implementasi yang melibatkan lembaga TK lain sehingga hasil penelitian benar-benar dapat memiliki kebermanfaatan untuk pengembangan motorik kasar anak usia 5-6 tahun.

\section{UCAPAN TERIMA KASIH}

Ucapan terima kasih disampaikan kepada Universitas Nusantara PGRI Kediri melalui program stimulus dana penelitian melalui LPPM sangat bermanfaat dalam pencapaian luaran penelitian yang dihasilkan oleh peneliti bersama anggota dalam upaya meningkatkan kinerja dosen dan kolaaborasi bersama mahasiswa terkait publikasi ilmiah. Selain itu ucapan terima kasih kepada TK Perwanida Mrican Kecamatan Mojoroto Kota Kediri yang sudah bersedia menjadi mitra dalam pengambilan data penelitian.

\section{DAFTAR PUSTAKA}

Andriani, Y., Nasirun, M., \& D., D. (2019). Meningkatkan Motorik Kasar Pada Anak Melalui Permainan Estafet Pada Anak Kelompok B Taman Kanak-Kanak Lestari Desa Srikaton Blok V Kecamatan Pondok Kelapa Kabupaten Bengkulu Tengah. Jurnal Ilmiah POTENSIA, 4(1), 32-40. https:// doi.org/10.33369/jip.4.1.32-40

Angraini, R., Tiara, M., Waldi, A., \& N, N. (2019). Penggunaan Media Gambar dalam Menanamkan Nilai-nilai Pancasila pada Anak Usia Dini. JED (Jurnal Etika Demokrasi), 4(1). https://doi.org/10.26618/jed.v4i1.2084

Ardini P, \& Lestariningrum A. (2018). Bermain dan Permainan Anak usia Dini Sebuah Kajian Teori dan Praktik. Kencana, 1, 236. https://doi.org/10.52266/pelangi.v1i1.283

Arifiyanti, N. (2020). The Gross Motor Skill Differences Between Preschool Boys and Girl. Aulad: Journal on Early Childhood, 3(3), 115-120. https:// doi.org/10.31004/aulad.v3i3.78

Asriansyah, A., \& Mahendra, A. (2020). Model Permainan Perseptual Motorik Melalui Ban Motor Bekas Dalam Pendidikan Jasmani Pada Siswa Sekolah Dasar. Jendela Olahraga, 5(2), 122-130. https://doi.org/10.26877/jo.v5i2.6208

Gall, J., Gall, M. D., \& Borg, W. T. (2005). Applying educational research (5th ed.). In Pearson Education Limited.

Honrubia-Montesinos, C., Gil-Madrona, P., \& Losada-Puente, L. (2021). Motor development among spanish children. Children, 8(1). https:// doi.org/10.3390/children8010041

Indriharta, L., \& Pembangunan, U. (2006). Bola Keranjang. 5(April), 42-52. 
Jannah, A. R., \& Lestariningrum, A. (2018). Peningkatan Kemampuan Motorik Kasar Anak Usia 5-6 Tahun Melalui Permainan Injak Ekor. Journal of Early Childhood Care and Education, 1(1), 1. https:/ / doi.org/10.26555/jecce.v1i1.5

Komaini, A. (2017). Peningkatan Keterampilan Gerak Dasar (Fundamental Motor Skills) Anak Melalui Pendekatan Bermain Murid Taman Kanakkanak Kota Padang. Jurnal Sains Keolahragaan Dan Kesehatan, 2(2), 54. https:// doi.org/10.5614/jskk.2017.2.2.6

Mahmud, B. (2019). Urgensi stimulasi kemampuan motorik kasar pada anak usia dini. $\begin{array}{lll}\text { DIDAKTIKA : } \quad \text { Jurnal } & \text { Tependidikan, }\end{array}$ https://doi.org/10.30863/didaktika.v12i1.177

Novianti, R., \& Garzia, M. (2020). Penggunaan Gadget pada Anak; Tantangan Baru Orang Tua Milenial. Jurnal Obsesi: Jurnal Pendidikan Anak Usia Dini, 4(2), 1000. https://doi.org/10.31004/obsesi.v4i2.490

Nugraha, B. (2015). Pendidikan Jasmani Olahraga Usia Dini. Jurnal Pendidikan Anak, 4(1). https://doi.org/10.21831/jpa.v4i1.12344

Nuridayu, N., Kiya, A., \& Wahyuni, I. W. (2020). Pengembangan Motorik Kasar Anak Usia Dini Melalui Permainan Gerakan Binatang. As-Sibyan: Jurnal Pendidikan Anak Usia Dini, 5(2), 107-120. https:// doi.org/10.36456/incrementapedia.vol2.no02.a3018

Putri, A. F. I. (2019). Pengembangan motorik kasar pada anak usia 5-6 tahun melalui permainan melempar dan menangkap bola di taman kanak-kanak para bintang kecamatan kota baru jambi. In UIN Sutha Jambi. https://doi.org/10.30870/jpppaud.v5i2.4703

Rahma, A., \& Kastrena, E. (2020). Peningkatan Kemampuan Gerak Manipulatif Melalui Permainan Bowling Botol. MAENPO, 9(2), 48. https://doi.org/10.35194/jm.v9i2.908

S., T. S., Nasirun, M., \& D, D. (2020). Aplikasi Gerak Lokomotor Sebagai Media Untuk Meningkatkan Kemampuan Motorik Kasar Pada Kelompok B1. Jurnal Ilmiah Potensia, 5, 1. https:// ejournal.unib.ac.id/index.php/potensia/article/view/8188

Safitri, S., \& Izzati, I. (2021). Pelaksanaan Pengembangan Motorik Kasar Di Taman KanakKanak Harapan Pangian Lintau Buo. Indonesian Journal of Early Childhood (IJEC), 5(2). http://jurnal.unw.ac.id/index.php/IJEC/article/view/986

Siregar, A. E. P. (2018). Pembelajaran Motorik. Universita Negeri Medan.

Sukmana, Abdian Asgi. Mutohir, Toho cholik. Muhyi, M. (2021). Permainan krawnjang (Kids Takraw Indonesia). In Jakad media Publishing.

Sumiyati, S. (2018). Metode Pengembangan Motorik Kasar Anak Usia Dini. AWLADY : Jurnal Pendidikan Anak, 4(1), 78. https://doi.org/10.24235/awlady.v4i1.2509

Syafril, S., Kuswanto, C. W., Farida, \& Muriyan, O. (2020). Dua Cara Pengembangan Motorik Kasar Pada Anak Usia Dini Melalui Gerakan-Gerakan Senam. Jurnal Pelita PAUD, 5(1), 104-113. 